\title{
INTERVENTION BEFORE THE INTERNATIONAL COURT OF JUSTICE*

\author{
THE NICARAGUAN INTERVENTION IN EL SALVADOR/HONDURAS CASE
}

\author{
Mariano GARCÍA RUBIO ${ }^{* *}$
}

RESUMEN: Algunas cuestiones sobre la intervención de terceros Estados ante la Corte Internacional de Justicia se aclararon con la decisión de la intervención de Nicaragua en el caso El Salvador/Honduras. Es claro que la Corte carece de facultades para hacer la intervención obligatoria, que la intervención es un incidente en el procedimiento; y que el incidente debe referirse al fondo del caso, y no cuestiones preliminares. Sobre esta base, la decisión de la intervención de Nicaragua clarificó que la Sala, y no la Corte, debía decidir sobre la intervención. La Sala requirió que el Estado interventor estableciera un interés, más que un derecho, personal y directo, de naturaleza jurídica, diferente de interés en reglas o principios generales. La intervención se autorizó sólo en algunas cuestiones. La solicitud de reconocimiento de un nuevo derecho sería una intervención impropia, y se requeriría además de un lazo jurisdiccional. Ése no es el caso de la solicitud de Nicaragua para salvaguardar sus intereses en el golfo de Fonseca, y por lo tanto, no ha lugar la posición de Nicaragua como parte en el caso. La interpretación de los requisitos en el artículo 81 de las Reglas de la Corte continúa siendo oscura.
ABSTRACT: Certain issues on third party intervention before the International Court of Justice were clarified by the decision on the Nicaraguan intervention on the Salvador/ Honduras case. It is clear that the court lacks the power to make intervention compulsory; that intervention is an incident in the procedure; and, that the incident must concern the merits and not preliminary issues. On these grounds, the decision in the Nicaraguan intervention clarified that the Chamber, rather tan the whole Court, was to decide on the intervention. The Camber requested that the intervener assessed a personal and concrete interest, rather than a right, of a legal nature, different from an interest in general rules or principles. Intervention was authorised only in some issues. The request to recognise a new right would be an improper intervention and a jurisdictional link would be necessary. Such is not the case of Nicaragua's application to safeguard its interests in the Gulf of Fonseca, and thus, gives no rise to the position of Nicaragua as a party to the case. The interpretation of the requirements in article 81 of the rules of the Court remains, nevertheless, unclear.

* The case law included in this article is the one available up to September 1999.

** Teaching and Research Assistant, The Graduate Institute of International Studies, Geneva. 
SUMMARY: I. Preliminary remarks. II. Intervention under articles 62 and 63 of the Statute of the Court. III. The Nicaraguan intervention in Honduras/El Salvador. IV. Final remarks. V. Bibliography.

\section{PRELIMINARY REMARKS}

The posibility of third-party intervention in civil procedures is generally recognized in domestic legal systems. As Professor Habscheid pointed out in his complete study of comparative law annexed to Malta's application for permision to intervene in the Continental Shelf case (Tunisia/Libyan Arab Jamahiriya), ${ }^{1}$

...(T)ous les systèmes de procedure civile permettent — dans une forme ou l'autre- à un tiers intéressé de s'immiscer dans un procès civil pendant entre un demandeur et un défendeur, soit de sa propre initiative, soit sur admission ou invitation par le tribunal. Le procès civil est, certes, d'abord une affaire entre ses deux parties. Mais il est incontestable que le jugement, malgré le fait qu'il aura, en principe, autorité de chose jugée entre les parties seulement, peut influencer ausi les intérèts de tierces personnes. ${ }^{2}$

In international law, the acceptance of the institution of intervention proceeds from the assumption that the provision of article $59^{3}$ of the Statute of the International Court of Justice (res inter alios acta) might not be enough to adequately protect the legal interests of third States in contentious proceedings. ${ }^{4}$

The Statute envisages two types of intervention: discretionary intervention when a State considers that it has an interest of a legal nature

1 1982, ICJ Reports, p. 18.

2 Habscheid, Walther J., "Les conditions de l'intervention volontaire dans un procès civil", in International Court of Justice (Pleadings, Oral Arguments, Documents), Case Concerning the Continental Shelf (Tunisia/Libyan Arab Jamahiriya, vol. III, p. 478).

3 Article 59: The decision of the Court has not binding force except between the parties and in respect of that particular case.

4 Sir Robert Jennings noted in his opinion in Case Concerning the Continental Shelf (Libyan Arab Jamahiriya/Malta): Application by Italy for Permission to Intervene, that "the principles of a decision of a judgment are not binding in the sense that they might be in some common law systems through a more or less rigid system of binding precedents. But the slightest acquaintance ith the jurisprudence of this Court shows that Article 59 does by no manner of means exclude the force of persuasive precedent. So the idea that Article 59 is protective of third States' interest in this sense at least is illusory", ICJ Reports 1984, p. 158. 
which may be affected by the decision of a case to which it is not a party (article 62); and intervention as of right when a State is party to a treaty the interpretation of which is in issue before the Court (Article 63).

States have been to some extent reluctant to invoke these provisions before the Court. Since the establishment of the Permanent Court of Justice in 1922, there have been only five attemps of intervention under article $62^{5}$ and three declarations of intervention under article 63.6

For its part, the Court had been unwilling to break the classical bilateralism which characterizes every international jurisdiction. While two of the declarations of intervention under article 63 were admitted, ${ }^{7}$ every attempt of intervention under article 62 was, until 1990, systematically rejected. As a consequence, the institution of intervention in general, and that provided for in article 62 in particular, were considered as practically dead letter in the Statute of the Court. ${ }^{8}$

The acceptance by a Chamber of the Court of the application for permission to intervene introduced by Nicaragua in the Case Concerning the Land, Island and Maritime Frontier Dispute (El Salvador/Honduras) ${ }^{9}$ substantially changed this scenario and renewed the interest of scholars on the subject. A very rich literature covering different aspects of intervention has since then been published. ${ }^{10}$

On 30 June 1999, the International Court of Justice informed that the Republic of Equatorial Guinea has filed an Application for permission to intervene in the case concerning Land and Maritime Boundary between

5 Nuclear Tests cases (Australia/France; New Zealand/France): Application by Fiji for Permission to Intervene, Order, ICJ Rep. (1973) pp. 320 and 324 and ICJ Rep. (1974), pp. 530-538; Case Concerning the Continental Shelf (Tunisia/Libyan Arab Jamahiriya): Application by Malta for Permission to Intervene, ICJ Rep. (1981), p. 3-40; Case Concerning the Continental Shelf (Libyan Arab Jamahiriya/Malta): Application by Italy for Permission to Intervene, ICJ Rep. (1984), pp. 3-160; and Case Concerning the Land, Island and Maritime Frontier Dispute (El Salvador/Honduras)

6 S. S. Wimbledon case, 1923, P.C.I.J. Rep. (Serie A, No.1, 5) 9-14; Haya de la Torre Case (Colombia v. Peru), 1951, I.C.J. Rep. 71, at 73-77 and Military and Paramilitary Activities in and against Nicaragua, ICJ Reports 1986.

7 Poland in the SS Wimbledon Case and Cuba in the Haya de la Torre Case.

8 Judge Ago in his dissenting opinion in Italy's intervention application stated that "the decision on the present case may well sound the knell of the institution of intervention in international legal proceedings" (p. 130, para. 22). By his part, Judge Schwebel said regarding the judgement in the same case: "it is virtually tatamount to reading Article 62 of the Statute" (p. 134, para. 10).

9 Case Concerning the Land, Island and Maritime Frontier Dispute (El Salvador/Honduras), Application by Nicaragua for Permission to Intervene, ICJ Reports, 1990.

10 We suggest, for a comprehensive analysis in English language Rosenne, Shabtai; Intervention in the Interntional Court of Justice, (Nova et vetera iuris gentium. Series A, Modern International Law; núm. 17), Martinus Nijhoff Publishers, Dordrecht/Boston/London, 1993. 
Cameroon and Nigeria (Cameroon v. Nigeria). Although Equatorial Guineamade it clear that it did not seek neither to become a party to the case nor to intervene in those aspects of the proceedings that relate to the land boundary between Cameroon and Nigeria, this is an excellent opportunity for the Court to review the findings of the Chamber in the El Salvador/Honduras case. ${ }^{11}$

While waiting for that decision, we propose in the following pages a study of some of the legal aspects that the study of intervention involves. We will concentrate first on the legal nature and common features of intervention both under articles 62 and 63 of the Statute of the Court.

In the second part we will focus on the conditions under which the Nicaraguan intervention was granted on the grounds of article 62 of the Statute in the El Salvador/Honduras case.

An attempt to identify remaining problems and a overall conclusion can be found in our final remarks.

\section{INTERVENTION UNDER ARTICLES 62 AND 63 OF THE STATUTE OF THE COURT}

\section{a) Discretionary intervention and intervention "as of right": concept and limits}

The Statute of the International Court of Justice provides for intervention in Articles 62 and 63. They read as follows:

Article 62

(1) Should a State consider that it has an interest of a legal nature which may be affected by the decision in the case, it may submit a request to the Court to be permitted to intervene.

(2) It shall be for the Court to decide upon this request. ${ }^{12}$

11 International Court of Justice, Press Communiqué 99/35.

12 The procedure governing intervention under Article 62 is regulated by Article 81 of the Rules of the Court:

1. An application for permission to intervene under the terms of Article 62 of the Statute, signed in the manner provided for in Article 38, paragraph 3, of these Rules, shall be filed as soon as possible, and no later than the closure of the written proceedings. In exceptional circumstances, an application submitted at a later stage may however be admitted.

2. The application shall state the name of an agent. It shall specify the case to which it relates, and shall set out:

(a) the interest of a legal nature which the State applying to intervene considers may be affected by the decision in that case; 


\section{Article 63}

1. Whenever the construction of a convention to which states other than those concerned in the case are parties is in question, the Registar shall notify all such states forthwith.

2. Every state so notified has the right to intervene in the proceedings; but if it uses this right, the construction given by the judgment will be equally binding upon it. ${ }^{13}$

It emerges that there is a clear difference of wording between Articles 63 and $62 .{ }^{14}$ Whereas article 62 only grants the "option" or "faculty" of requesting permission to intervene, Article 63, on the other hand, speaks of the "right" to intervene.

\section{This difference proceeds from the assumption that all parties necessa-} rily have an interest in the contruction of multilateral treaties. The very nature of a multilateral convention enables a multiplicity of interests po-

(b) the precise object of the intervention;

(c) any basis of jurisdiction which is claimed to exist as between the State applying to intervene and the parties to the case.

3. The application shall contain a list of the documents in support, which documents shall be attached.

For an analysis of Article 81 and its application by the Registar of the Court, see Guyomar, Geneviève, Commentaire du Règlement de la Cour Internationale de Justice, Paris, Pedone, pp. 525-533.

13 The procedure to be followed in cases of declaration of intervention under article 63 of the Statute are governed by article 82 of the Rules of the Court, which reads as follows:

1. A State which desires to avail itself of the right of intervention conferred upon it by Article 63 of the Statute shall file a declaration to that effect, signed in the manner provided for in Article 38, paragraph 3, of the Rules. Such a declaration should be filed as soon as possible, and not later than the date fixed for the opening of the oral proceedings. In exceptional circumstances a declaration submitted at a later stage may however be admitted.

2. The declaration shall state the name of an agent. It shall specify the case and the convention to which it relates and shall contain:

(a) particulars of the basis on which the declarant State considers itself a party to the convention;

(b) identification of the particular provisions of the convention the construction of which it considers to be in question.

(c) statement of the construction of those provisions for which it contends;

(d) a list of the documents in support, which documents should be attached;

3. Such a declaration may be filed by a State that considers itself a party to the convention the construction of which is in question but has not received the notification referred to in Article 63 of the Statute.

For an analysis of Article 82 and its application by the Registar of the Court, see Guyomar, Geneviève, Commentaire du Règlement de la Cour Internationale de Justice, Pedone, Paris, pp. 534-542.

14 For an exhaustive analysis of the wording of Article 63 see Hambro, Edvard, "Intervention under Article 63 of the Statute of of the International Court of Justice", Il Processo InternazionaleStudi in Onore di Gaetano Morelli, Milano, 1975, pp. 387-400. 
tentially to emerge in litigation. Despite article 59, a judicial interpretation of a treaty provision will clearly have considerable impact and may be utilized by parties and non parties.

The decision of the Court rejecting El Salvador's demand of intervention in the Nicaragua case showed that article 63 does not grant an "automatic" or "absolute" right to intervene. ${ }^{15}$

Hambro has contended that the Court, in spite of the categorical wording of article 63 retains the power to decide whether a State has the right to intervene. ${ }^{16}$ Should this position be correct, there would be no difference between intervention under articles 62 and 63. The Court would retain in both cases a considerable degree of discretion regarding a demand of intervention. We share the position of Fitzmaurice, who threw light on the question in the following terms:

Although intervention under this Article (63) is as of right, provided the conditions stated in it are fulfilled, it is naturally for the Court to decide whether they are actually satisfied or not... Given that these conditions are present, the Court is bound to admit the intervention, and has no discretionary power in the matter, as it would seem it would have under Article $62 . .17$

Unlike intervention "as of right", which was already provided for in the 1899 and 1907's Hague Conventions, ${ }^{18}$ the notion of discretionary intervention provided for in article 62 is based on intervention in civil procedures in domestic systems. ${ }^{19}$

The Court has pointed out that it has no power to reject a request for intervention on overriding policy grounds. ${ }^{20}$ But it is evident that the lack of clarity in the wording of article 62 on such essential concepts as "inte-

15 For a criticism of the decision taken by the Court see Sztucki, Jerzy, "Intervention under Article 63 of the ICJ Statute in the Phase of Preliminery Proceedings: The 'Salvadorian Incident'”, AJIL, vol. 79, núm. 4, October 1985, pp. 1005-1036.

16 Hambro, op. cit., p. 397.

17 Fitzmaurice, "The Law and Procedure of the International Court of Justice, 1951-4", BYIL, 1958, p. 127.

18 On the influence of these Conventions in the elaboration of the Statute of the PCIJ, see dissenting opinions of Judges Sette-Camara and Oda in ICJ Reports 1984, pp. 71-2, parr. 6 and 7; pp. $100-1$, parr. 22 to 24 , respectively.

19 For a historical background of article 62 see Oda, Shigeru, "Intervention in the International Court of Justice. Articles 62 and 63 of the Statute", Völkerrecht als Rechtsordnung Internationale Gerichtsbarkeit Menschenrechte-Festchrift für Hermann Mosler, pp. 629-648.

201981 ICJ Reports at 12. 
rest of a legal nature", coupled with the determination by the Court that it must decide upon the proper purposes of intervention, makes forming value judgments inevitable. ${ }^{21}$ The margin for discretion is so broad that one of the counsels for Nicaragua in the Honduras/El Salvador case pointed out that, "nous avons l'impression que quelle que soit la présentation faite par le requérant, la Cour trouvera toujours une argumentation por le rejeter, que la série de formules qui ne lui plaisent pas est inépuisable et que celles qui pourraient lui plaire ne sont pas connues ou n'ont pas été découvertes". 22

Nothwistanding the substantial differences among both types of intervention, they share a number of basic features.

\section{b) Legal nature and common features of intervention under both Articles}

\section{b.1) Intervention is voluntary}

Intervention before the International Court of Justice remains absolutely voluntary. The Court has stressed "...the absence in the Court's procedures of any system of compulsory intervention, whereby a third State could be cited by the Court to come in as a party...". ${ }^{23}$

In Certain Phosphates of Nauru, the Court was even more specific in stating that

National Courts, for their part, have more often than not the necessary power to order proprio motu the joinder of third parties who may be affected by the decision to be rendered; that solution makes it possible to settle a dispute in the presence of all parties concerned. But on the international plane the Court has not such a power. Its jurisdiction depends on the consent of States and, consequently, the Court may not compel a State to appear before it, even by way of intervention. ${ }^{24}$

21 Judge Jennings recognized in his dissenting opinion in Italy's intervention application that the role of the Court is no more than "to decide whether the requirements of intervention under Article 62 are complied with or not", but in doing so, the Court clearly has to exercise a considerable measure of appreciation of the particular situation in coming to its decistion. ICJ Reports 1984, p. 151 , paragraph 9 .

22 C4/CR 5 June, 1990/2, p. 92.

23 ICJ Reports 1984, p. 25; p. 40.

24 ICJ Reports, 1992, p. 260; p. 53. 
For that reason, the lack of intervention of a State whose interest may be affected in the way contemplated by article 62 (1) has as a consequence the end of the proceedings.

In the Monetary Gold Removed from Rome in 1943 case $^{25}$ the Court found that

Albania has not submitted a request to the Court to be permitted to intervene. In the present case, Albania's legal interests would not only be affected by a decision, but would form the very subject-matter of the decision. In such a case, the Statute cannot be regarded, by implication, as authorizing proceedings to be continued in the absence of Albania. ${ }^{26}$

The same principle was invoked by Italy in its attempt to intervene in the Continental Shelf case (Libya/Malta), and the Court reasoned as follows:

But the question is not whether the partiipation of Italy may be useful or even necessary to the Court; it is whether, assuming Italy's non participation, a legal interest of Italy is en cause, or is likely to be affected by the decision. In the absence in the Court's procedures of any system of compulsory intervention, whereby a third State could be cited by the Court to come in as a party, it must be open to the Court, and is indeed its duty, to give the fullest decision it may in the circumstances of each case, unless of course, as in the case of the Monetary Gold Removed from Rome in 1943, the legal interest of the third State "would not only be affected by a decision, but would form the very subject matter of the decision" (ICJ Reports 1954 , p. 31), which is not the case here. ${ }^{27}$

\section{b.2) Intervention as an incident to the proceedings (Haya de la Torre)}

Almost thirty years after the first case of intervention before the PCIJ in the SS Wimbledon case, the International Court of Justice had the opportunity to deal in more detail with the institution sub examine when Cuba filed a declaration of intervention under Article 63 in the Haya de la Torre case. ${ }^{28}$ 
Taking into consideration the objections presented by Peru, in that the intervention sought by Cuba was in fact an attempt to appeal against the decision of the Court in the Asylum case, ${ }^{29}$ the Court stated that

...every intervention in incidental to the proceedings in a case; it follows that a declaration filed as an intervention only acquires that character, in law, if it actually relates to the subject-matter of the pending proceedings. The subject-matter of the present case differs from that of the case which was terminated by the Judgment of November 20th, 1950: it concerns a question - the surrender of Haya de la Torre to the Peruvian authorities - which in the previous case was completely outside the Submissions of the Parties, and which was in consequence in no way decided by the above-mentioned Judgment. ${ }^{30}$

Nevertheless, the Cuban Agent contended at the hearing that the Court was required to interpret new aspects of the Havana Convention not subject to the Court's determination in the Asylum case. The Court partially admitted the contention and granted Cuba's intervention "reduced in this way, and operating within these limits...". ${ }^{31}$

\section{b.3) Intervention during preliminary phases}

Having established that intervention is incidental to the proceedings in a case, it now remains to be seen whether the incident must relate only to the main proceedings or, on the contrary, may relate to another incident (i.e. preliminary objections).

In referring to "cases", the wording of Article 63 seems to suggest that intervention is an incident regarding the merits of a case and not "an incident of an incident".

This was indeed the view adopted by the a Chamber of the Court in the most recent case of intervention under Article 63. In the Case concerning Military and Paramilitary Activities in and against Nicaragua, ${ }^{32}$ the Court found the declaration of intervention inadmissible "inasmuch as it relate(d) to the current phase of the proceedings" ${ }^{33}$ It should be noted that at the time of the submission of the declaration of intervention the 
proceedings on the merits of the case were suspended pending the Court's determination on whether it had jurisdiction to entertain Nicaragua's application and whether the application was admissible. Once the Court found it had jurisdiction and declared admissible the application, it stated that El Salvador, Honduras and Costa Rica, which the US had argued would be affected by the judgment of the Court, "are free to resort the incidental procedures of intervention under Articles 62 and 63 of the Statute, to the second of which El Salvador has already unsuccessfully resorted in the jurisdictional phase of the proceedings, but to which it may revert in the merits phase of the case". ${ }^{34}$

Some criticism may be addressed to this decision given that, as Judge Schwebel expressed in his dissenting opinion

There are multilateral conventions that, in a whole or in a part, relate to jurisdictional questions. Their construction by the Court in a case between two States can affect the legal position of a third State under such conventions no less than it can affect their position under other conventions, or parts of other conventions, whose clauses are substantive rather than jurisdictional. ${ }^{35}$

Judge Schwebel further points out that the notification envisaged in Article 63, paragraph 1 , have been sent on several ocasions throughout the Court's history specifically relating to the preliminary objections phase. ${ }^{36}$

\section{THE NICARAGUAN INTERVENTION IN HONDURAS/EL SALVADOR}

\section{a) The background}

The Gulf of Fonseca is a bay located on the western coast of Central America. It is approximately 19 miles wide at its entrance points and penetrates some 32 miles into the coastline. The coastline of El Salvador lies to the north west of the Gulf and that of Nicaragua to the south east, the entrance points of the Gulf being formed by the mainlands of these

34 ICJ Reports 1984, p. 425.

35 ICJ Reports, 1984, p. 235.

36 Judge Schwebel refers to the following cases: Appeals from Certain Judgmentsof the Hungaro-Czechoslovak Mixed Arbitral Tribunal (PCIJ, ser. C, N 68, 1932); Pajzs, Csáky, and Esterházy (PCIJ, ser. C, N 80, 1935.); Phospathes in Morocco (PCIJ, ser. C, N 85, 1936); Corfu Chanel (1948 ICJ Reports); Anglo-Iranian Oil Co. (ICJ Pleadings (Anglo-Iranian Oil Co.); and Nuclear Tests cases (ICJ Pleadings (2 Nuclear Tests). 
two countries. A substantial part of the inner shoreline of the Gulf is formed by the mainland of Honduras.

In $1916 \mathrm{El}$ Salvador brought a case against Nicaragua, alleging that by concluding the Bryan-Chamorro treaty with the United States, which allowed, inter alia, for the construction of a naval base bordering upon the Gulf of Fonseca, Nicaragua was violating the rights of co-ownership which El Salvador possessed in the waters of the Gulf. The Central American Court of Justice decided that the Gulf of Fonseca was an "historic bay" and declared El Salvador, Honduras and Nicaragua to be co-owners of its waters. ${ }^{37}$

In 1980 a General Peace Treaty was concluded between El Salvador and Honduras. This, in part, determined the course of their land boundary. Some sections of that land boundary remained, however, undelimited. In addition, the two countries disputed sovereignty over a number of islands located in the Gulf. In 1986 El Salvador and Honduras submitted, by special agreement, a request that a Chamber of the International Court of Justice be established in order:

1. to establish the frontier line in the areas or sections not described in Article 16 of the General Peace Treaty of 30 October 1980.

2. to determine the legal situation of the islands and maritime spaces. ${ }^{38}$

b) The application for permission to intervene.

\section{b.1) Who decides?}

In Nicaragua's view, the dispute relating to the legal situation of the islands and maritime areas both within and adjacent to the Gulf of Fonseca was of a trilateral, rather than a bilateral, character. As only two out of the three States involved (Honduras and El Salvador) had created the timetable and the procedural agenda from which Nicaragua had been excluded, "...(T)he practical consequence of a favourable response to the present request will be the reformation of the Chamber as presently constituted and the re-ordering of the written proceedings as arranged by the Order of 27 May 1987". 39 
In the alternative, Nicaragua contended that

the Court should, in any case, exclude from the mandate of the Chamber any powers of determination of the juridical situation of maritime areas both within the Gulf of Fonseca and also in the Pacific Ocean and, in effect, limit the Chamber's mandate to those aspects of the land boundary which are in dispute between El Salvador and Honduras. ${ }^{40}$

In the view of the Applicant, the matter raised by it was "exclusively within the procedural mandate of the full Court, not only because it is an incidental proceeding but also for... reasons of elemental equity (that of consent and that of the equality of States)". ${ }^{41}$ By its decision of 14 December 1989 the Court afforded the two parties to the case: "the opportunity of submitting to the Court their observations on the question... raised (by Nicaragua), i.e., whether the Applicant for permission to intervene is to be decided by the full Court or by the Chamber...". ${ }^{42}$

\section{b.2) The reaction of the principal parties}

In its observations submitted on 15 January 1990, the Government of Honduras adopted the view according to which "( $\mathrm{t}$ )he full Court has no juridiction over the case between Honduras and El Salvador..." and that "Nicaragua's application to intervene must be heard by the Chamber and not by the full Court".

The Government of El Salvador, for its part, informed to the Court of its intention "to oppose the Nicaraguan application to intervene, including the request for reformation of the Chamber...". At the same time, it did not reject a priori the possibility that the full Court might consider Nicaragua's application:

"Believing that the reasons for opposing the application are equally valid before the full Court or before the Chamber, the Government of El Salvador has no observations to make on the preliminary question of whether the Nicaraguan application falls within the jurisdiction of the Chamber or that of the full Court". 


\section{b.3) The decision of the Court}

The Court, in its Order rendered on 28 February 1990, ruled that "it is for the Chamber formed to deal with the present case to decide whether the application for permission to intervene under Article 62 of the Statute filed by the Republic of Nicaragua... should be granted". ${ }^{43}$ The decission was taken on the grounds that "every intervention is incidental to the proceedings in a case" 44 and that "a chamber formed to deal with a particular case therefore deals not only with the merits of the case, but also with incidental proceedings arising in that case". ${ }^{45}$

The Order was adopted by twelve votes to three. ${ }^{46}$ In his dissenting oppinion, Judge Elias raised the question as to whether the negative attitude of the principal parties vis-à-vis Nicaragua's application for intervention could have some impact on the way the Applicant's request might be considered by the Chamber.

It should be remembered that the Court had said in Italy's application to intervene that the position of the parties is only one of the elements to be considered ${ }^{47}$ Judge Mbaye stated in his separate opinion that the opposition to the application to intervene by the parties is "not decisive". ${ }^{48}$ However, it could be argued that the opinion of the parties can strongly influence the Court's decision concerning an application for permission to intervene, and that that influence is even greater when the case is dealt with by a chamber.

Article 17, paragraph 2 of the 1978 Rules of the Court requires the President of the Court to ascertain and report to the Court the views of the parties regarding the composition of an ad hoc chamber before the Court elects Members of the Court to be members of the chamber. But practice shows that from 1982 until the case sub examine the composition of the four chambers formed by the Court responded exactly to the wishes of the parties in dispute. ${ }^{49}$

43 ICJ Reports 1990, p. 6.

44 The Court quoted its decision in the Haya de la Torre case, ICJ Reports 1951, p. 76.

45 The Court refered here to the precedent in the Frontier Dispute case, Provisional Measures, Order of 10 January 1986, (ICJ Reports 1986, p. 3) and Elettronica Sicula S.p.A (ELSI), (ICJ Reports 1989, p. 42, para. 49).

46 In favor President Ruda, Vice-President Mbaye; Judges Lachts, Oda, Ago, Schwebel, Sir Robert Jennings, Bedjaoui, Ni, Evensen, Guillaume and Pathak. Against Judges Elias, Tarassov and Shahabuddeen.

47 ICJ Reports 1984, p. 28.

48 ICJ Reports 1984, p. 48.

49 Gulf of Maine (Canada/USA); Frontier Dispute (Burquina Faso/Mali), Elettronica Sicula 
In this case the agreement of the parties regarding the number and the names of the judges was an "essential condition" for the constitution of the chamber, according to article 1.1 of the compromis. ${ }^{50}$ This de facto power of the parties to a dispute in the election of the members of a chamber of the Court produces, as Abi-Saab pointed out, an "arbitralization" of the Court. ${ }^{51}$ Moreover, it clearly conditioned future decisions of the chamber given that the parties could put an end to the proceedings by simply withrawing the compromis if both were not satisfied with the course of the proceedings.

In this circumstance, as in arbitral procedures, the parties concerned enjoy almost propriety rights over the proceedings, and that is the reason by which intervention is excluded in cases of arbitration. ${ }^{52}$ Therefore, the argument that the chamber deals not only with the merits but also with incidental proceedings arising in a case seems to lose some of its strength if we consider that the composition of the chamber was entirely determined by the parties.

The institution of intervention presents a particular feature when compared to other incidental proceedings. Unlike provisional measures or preliminary exceptions, it implies a judgement on the legal interest of a non-party State. Such a judgement cannot respect the principle of equality of States "....without appropiate action taken by the full Court within the framework of the very special relationship existing between itself and the Chamber". 53

Despite this criticism, Nicaragua activated the normal procedure of intervention under article 62 before the Chamber, recognizing that "the

S.p.A. (ELSI) (USA/Italy) and Land, Island and Maritime Delimitation Dispute (El Salvador/Honduras). See Riquelme Cortado, Rosa Ma, La intervención de terceros Estados en el proceso internacional, Madrid, Tecnos, 1993, p. 45-46. In the same sense Kohen, Marcelo, "La requête à fin d'intervention du Nicaragua dans l'affaire du Differend Frontalier Terrestre, Insulaire et Maritime (El Salvador/Honduras). L'Ordonnance de la Cour du 28 fèvrier 1990 et l'arrêt de la Chambre du 13 septembre 1990", Annuaire Français de Droit International, XXXVI, 1990, pp. 344-345.

50 ICJ Reports, 1990, p. 95.

51 Abi-Saab, Georges, "De l'evolution de la Cour Internationale. Reflexions sur quelques tendances recentes", Revue Générale de Droit International Public, pp. 287 y ss.

52 Ibidem, p. 289.

53 Judge Shahabuddeenn dissenting opinion, ICJ Reports, 1990, pp. 61-62. Against this view, Judge Oda expressed that "...once a chamber has been constituted, the powers of the full Court are, in my view, limited, so far as the composition of that chamber is concerned, to the filling of any vacancy in the original constitution that may arise as a result of the death, resignation or incapacity of an original member of the chamber", ICJ Reports, 1990, p. 8. 
eventual decision of the Chamber granting or refusing permission to intervene will be binding and final...". ${ }^{54}$ Pursuant to article 83.1 of the Statute, the President of the Chamber asked the parties for written observations on their position regarding the intervention. El Salvador maintained its opposition already expressed before the full Court and added that the interests of Nicaragua were protected by article 59 of the Statute (res inter alios acta). Honduras, for its part, admitted the intervention to the extent that it would relate to a determination of the legal statute of the waters of the Gulf of Fonseca.

The application for permission to intervene submitted by Nicaragua to the Chamber did not include the claim for reform of the Chamber and re-ordering of the written proceedings, but this did not imply a resignation of that claim:

...the issue of whether the Application to intervene should be granted is anterior to the decision on whether it is proper for the Court to have formed the Chamber or on whether the composition of the Chamber should be altered. Therefore, now that Nicaragua is before the Chamber reiterating its petition to intervene, it does so without submitting to the Chamber on this opportunity the two questions that the full Court stated could be resolved after the decision on the Application for permission to intervene was made by the Chamber. ${ }^{55}$

In these circumstances, the Chamber proceeded to the analysis of the requirements set out by Article 62 of the Statut and Article 81 of the Rules of the Court.

c) The requirements of articles 62 of the statute and 81 of the rules of the court

Article 81 of the Rules of the Court stipulates the conditions which an application for permission to intervene should fulfill in order to be admitted by the Court. From the formal point of view, an application "shall be filed as soon as possible, and not later than the closure of the written proceedings" and shall state the name of an agent. ${ }^{56}$

54 ICJ Reports, 1990, p. 110.

55 C4/CR 5 June 1990/1, p. 16.

56 Article 81.1 of the Statute of the International Court of Justice. 
While articles 64 and 69 of the 1946 and 1972 Rules of the Court, respectively, required "a statement of law and of fact justifying intervention", paragraph 2 of article 81 of the 1978 Rules requires the applicant State to set out the interest of a legal nature which it considers may be affected by the decision in that case; the precise object of the intervention and any basis of jurisdiction which is claimed to exist as between the State applying to intervene and the parties to the case.

\section{c.1) Formal requirements in the Nicaraguan intervention}

Nicaragua introduced its application on 17 november 1989, two month before the deadline for the deposit of counter-memorials.

\section{c.2) The existence of an interest of a legal nature which may be affected by the decision in the case ${ }^{57}$}

Unlike the provision made for in article 63 of the Statute where the existence of a legal interest is presumed, ${ }^{58}$ under article 62 it was for $\mathrm{Ni}$ caragua to show that it has an interest of a legal nature which may be affected by part of the Judgment of the Chamber.

\section{c.2.1) General considerations}

Although the question as what constitutes such an interest continue to be elusive in the jurisprudence of the Court, certain parameters have been clarified.

A first distinction must be drawn between the concepts of "interest of a legal nature" and that one of "subjective rights". ${ }^{59}$ Judge Sette-Camara noticed that "...(O)f course parties coming before the Court claim

57 See Mbaye, "L'intérêt pour Agir devant la Cour International de Justice", 209 RDCADI, pp. 223-345 (1988-II).

58 The Permanent Court of International Justice had the opportunity to deal with intervention in the case concerning the SS Wimbledon, the first case it had before it. Although the application by Poland was originally filed under Article 62 of the Statute, the Court admitted the intervention under Article 63 noting that the interpretation of certain clauses of the Treaty of Versailles was involved and that Poland was one of the states parties to the Treaty. The change of attitude of Poland in the course of the proceedings made unnecessary for the Court "to consider and satisfy itself whether Poland's intervention in the suit before it is justified by an interest of a legal nature, within the meaning of Article 62 of the Statute". PCIJ, Serie A, núm. 1, p. 13.

59 The relationship between "interests" and "rights an obligations" has been developed by the Court in the South West Africa cases, where it held that interests only create rights and obligations when given juridical expression and clothed in legal form. ICJ Reports 1966, p. 34. 
the existence of rights. What is an interest of a legal nature but a claim to a right?" ${ }^{60}$ But the Chamber, for its part, made clear that a State applying to intervene does not have to show the existence of rights in need of protection, but merely an interest of a legal nature which may be affected. ${ }^{61}$

Such an "interest" is defined only by its legal nature. Therefore, purely economic or political interests seems to be excluded from the concept as far as they do not contain also a legal aspect. ${ }^{62}$

Article 62 remains silent as to whether the interest need be direct or even whether it need be substantial. ${ }^{63}$ Jiménez de Aréchaga, writing in an extra-judicial capacity, has pointed out that what is required is that a State presents to the Court a "submission in its own and direct interest, which are different from those of the original applicants and go beyond them" ${ }^{64}$ This position has been confirmed by the Chamber, who stated that applicants "have to be directly affected by a decision". ${ }^{65}$

In addition, the alleged interest should be personal and concrete regarding the intervening State. On this grounds the Court rejected the Maltese request for intervention:

"The interest of a legal nature invoked by Malta does not relate to any legal interest of its own directly at issue as between Tunisia and Libya in the present proceedings... It concerns rather the potential implications of reasons which the Court may give in its decision in the present case...". 66

A general interest in the development of certain rules or priciples of International law does not constitute a valid ground for intervention. As the Chamber stressed: “(T)he Chamber does not however consider that

60 Italian Intervention attempt, p. 83.

61 ICJ Reports 1990, p. 129.

62 The ICJ observed in the Hostages case that “...(N)ever has the view been put foward before that, because a legal dispute submitted to the Court is only one aspect of a political dispute, the Court should decline to resolve for the parties the legal questions at issue between them" (United States Diplomatic and Consular Staff in Teheran United States of America vs. Iran), 1980 ICJ Reports, p.20-37. Also the drafting commitee of the Advisory Committee of Jurists to the Permanent Court of International Justice in 1920 stated that "the essential point is to limit it to cases in which an interest of a legal nature can be shown, so that political intervention will be excluded" (PCIJ, Advisory Committee of Jurists, Proces-Verbaux of the Proceedings of the Committee, 1920, p. 749.

63 See sbmissions of P. Lalive, councel for Malta, in oral arguments, ICJ doc. CR 81/2 (Mar. 19).

64 Jiménez de Aréchaga, E., "Intervention under Article 62 of the Statute of the International Court of Justice", Völkerrecht als Rechtsordnung Internationale Gerichtsbarkeit MenschenrechteFestschrift für Hermann Mosler, Springer Verlag, Berlin-Heildelberg-New York, 1983, p. 458.

65 ICJ Reports 1990, p. 119, para. 66.

66 Maltese intervention, at 12. 
an interest of a third State in the general legal rules and principles likely to be applied by the decision can justify an intervention" ${ }^{67}$

\section{c.2.2. The legal interest shown by Nicaragua}

When Nicaragua presented its application for permission to intervene it made clear that its legal interests may be affected by the decision of the Chamber regarding the determination of the legal situation of the islands and maritime spaces of the Gulf of Fonseca (art.2.2 of the compromis). ${ }^{68}$ But the situation at that time was unclear in the sense that the parties were not in agreement as to the scope of art. 2.2 of the compromis. El Salvador, on the basis of the decision rendered by the Central American Court of Justice in 1917, contended that the Gulf was a condominium between the three parties and consequently excluded the possibility of any kind of delimitation of its waters:

The juridical situation of the Gulf of Fonseca, derived from its particular individual nature, does not permit the dividing up of the waters held in condominium precisely because what was in issue was not the recognition of common ownership of an object which is capable of being divided up but rather the definition of an object which had, for geographical reasons, an indivisible character given its configuration and dimensions. ${ }^{69}$

Honduras, on the contrary, contended that the Gulf was a historic bay creating a community of interest that in no way implied the abolition of frontiers but rather required the clear delimitation of them in order to facilitate cooperation among the riparian States. ${ }^{70}$ The delimitation included, in Hondura's view, that of the external waters of the Gulf up to 200 miles.

Nicaragua, for its part, contended that "the condominium, if it is declared to be applicable, would by its very nature involve three riparians, and not only the parties to the Special Agreement"71 and, citing the Monetary Gold Case, ${ }^{72}$ claimed that, since the case would determine the le-

67 ICJ Reports 1990, p. 124.

68 ICJ Reports, 1990, p. 100.

69 ICJ Reports, 1992, para. 409.

70 ICJ Reports, 1990, p. 120, para. 68.

71 Ibidem, p. 121.

72 Monetary Gold Removed from Rome in 1943, ICJ Reports, 1954. 
gal rights of Nicaragua in the Gulf of Fonseca, it would be improper for the Chamber to proceed without Nicaraguan participation. ${ }^{73}$

Concerning the delimitation of the waters within the Gulf, Nicaragua claimed it had a general interest in the relevant legal principles, although Honduras, which sought a delimitation of the Gulf, claimed that its proposals did not encroach on any areas of the Gulf that might be claimed by Nicaragua and that there were, therefore, no grounds for allowing intervention in this aspect. ${ }^{74}$

\section{c.2.3) The limited admission by the court: award 13/9/90}

The Chamber dismissed the applicability of the Monetary Gold argument. In that case it was improper to proceed without the participation of Albania because "a decision would determine a question of the international responsibility of Albania vis-à-vis Italy" and thus the legal position of Albania formed the very subject matter of the decision. However, in the case sub examine a determination of the opposability of the 1917 decision of the Central American Court of Justice as between El Salvador and Honduras did not require the Chamber to decide upon the validity of that award as between El Salvador and Nicaragua. For that reason, it could not be said that the Nicaraguan interest formed the very subjectmatter of the decision.

The Chamber noted that it was required to give a decision on various aspects of the overall dispute between the parties and considered "the possible effect on legal interests asserted by Nicaragua of its eventual decision on each of the different issues which might fall to be determined, in order to define the scope of any intervention which may be found to be justified under Article 62 of the Statute". ${ }^{75}$

\section{1) The legal situation of the islands}

The Chamber concluded that its decision on the legal situation of the islands would not affect the legal interests of Nicaragua:

Insofar as the dispute related to sovereignty over the islands, (the Chamber) should not grant permission for intervention by Nicaragua, in the ab- 
sence of any Nicaraguan interest liable to be directly affected by a decision on that issue. Any possible effects of the islands as relevant circumstances for delimitation of maritime spaces fall to be considered in the context of the question whether Nicaragua should be permitted to intervene on the basis of a legal interest which may be affected by a decision on the legal situation of the waters of the Gulf. ${ }^{76}$

\section{2) the situation of the waters of the Gulf}

The Chamber later found that independently of the existence of an objective legal regime of condominium in the Gulf (Nicaraguan and Salvadorian thesis) or a mere "community of interest" (Hondurian thesis), Nicaragua, as one of the three riparian State, was also interested in that question. ${ }^{77}$

\section{3) delimitation within the gulf}

However, the Chamber concluded that if it were to hold that there was not such condominium or community of interest in the Gulf, Nicaragua would not have a legal interest that may be affected by the Chamber's decision in the delimitation within or outside the Gulf. ${ }^{78}$

As we already mentioned, the Chamber also ruled that "it does not... consider that an interest of a third state in the general legal rules and principles likely to be applied by the decision can justify an intervention". 79

Other arguments advanced by Nicaragua, such as the potential relevance of the judgment regarding its security and navigational interests were also dismissed as being too general to justify intervention in any delimitation aspect of the case sub examine. ${ }^{80}$

76 Ibidem, p. 119.

77 Ibidem, p. 121.

78 Ibidem, pp. 126-128.

79 ICJ Reports 1990, p. 124. In the same line of reasoning, Jiménez de Aréchaga concluded that “...the travaux préparatoires of the Statute leads to the view that Art. 62 does not authorize intervention merely on the basis of a general interest in the development of International Law", in "Intervention under Article 62 of the Statute of the International Court of Justice", Völkettecht als Rechtsordnung Internationale Gerichtsbarkeit Menschenrechte-Festschrift für Hermann Mosler, Springer-Verlag, Berlin-Heidelberg-New York, 1983, pp. 453-465, at 458.

80 Ibidem, p. 78. 


\section{4) the waters outside the Gulf}

In spite of the controversy between Honduras and El Salvador as to whether the compromis allowed the Chamber to effectuate a delimitation of the waters outside the Gulf, both contested Nicaragua's contention that its legal interest would be affected by such a delimitation. ${ }^{81}$ Nicaragua failed in demonstrating how an eventual delimitation line would affect its interests, and the Chamber denied the intervention in this aspect of the case. $^{82}$

\section{5) The purpose of the intervention}

Article 81.2.b of the Rules of the Court provides that the application to intervene shall set out, inter alia, "the precise object of intervention".

It remains silent, however, whether intervention might follow the "principal", "accesory" or "assistance" models. These categories are known in municipal legal systems and depend whether the third State has a different legal interest vis-à-vis the principal parties, supports one of them, or whishes to intervene only to provide relevant information to the tribunal. ${ }^{83}$

In cases of "principal" intervention, in addition, the intervening State might wish only to "protect" what it considers to be its rights or obtain from the tribunal a formal recognition of them. This last possibility is closely linked, as we will see below, with the requirement of a "jurisdictional link" between the intervening State and the original parties to a case.

Although there is no reference in Article 62 to the "object" of an application to intervene, the Court has introduced the idea that certain purposes are legitimate and others are not. In its decisions, it has developed more extensively what will be regarded as improper purposes of intervention than the proper ones.

81 Ibidem, p. 81.

82 Ibidem, p. 84.

83 The intervention as "amicus curiae" of Yugoslavia has been admitted by the ICJ in the Corfu Channel Case. Nevertheless the decision seems to has been based in a general principle of law which would allows the tribunal to use all the legal means available in order to establish the veritable true in a case. See Bartos, Milan, "L'intervention Yougoslave dans l'affaire du Détroit de Corfou", Il Processo Internazionale. Studi in Onore di Gaetano Morelli, Milano, Giuffrè, 1975, pp. 41-51. 
In this regard, a first observation should be made with respect to the existing link between the object of the intervention and the legal interest of the intervening State. The Chamber has found that:

If a State can satisfy the Court that it has an interest of a legal nature which may be affected by the decision in the case, it may be permitted to intervene in respect of that interest. But that does not mean that the intervening State is then also permitted to make excursions into other aspects of the case. $^{84}$

Nevertheless, both concepts must not be confused. The object of the intervention and the legal interest, as Judge Sette-Camara stressed, “...are different and they diverge in their meaning and in their importance regarding the Court's decision", ${ }^{85}$

The object proposed by Nicaragua in its application for intervention was to safeguard its rights in the Gulf of Fonseca and in the adjacent maritime spaces as well as to inform the Chamber about its rights and interests en cause. This "conservative purpose" was an attempt to ensure "that the determination of the Chamber did not trench upon the legal rights and interests of the Republic of Nicaragua". ${ }^{86}$

The objections presented by El Salvador tended to confuse the object of the intervention with the merits of the case. In its view the Application was defective because Nicaragua did not indicate "its position with respect to the fundamental issue in the case, which is to define the object of the litigation and consequently the scope of the powers of the Chamber" ${ }^{87}$

The Chamber considered unnecessary to require from the applicant State an exhaustive account of its position on the merits at this initial stage and found that "It seems to the Chamber, however, that it is perfectly proper, and indeed the purpose of intervention, for an intervener to inform the Chamber of what it regards as its right or interests, in order to ensure that no legal interest may be 'affected without the intervener being heard...". 88

It should be noted that in the Maltese attempt to intervention, it was found that merely informing the Court of the interest of a legal nature that

86 ICJ Reports 1990, p. 108, para. 38 and p. 128, para. 86.

87 ICJ Reports, 1990, p. 111, para. 43 and 45.

88 ICJ Reports, 1990, p. 130. 
might be affected by its decision was insufficient to justify an intervention. In the case sub examine, on the contrary, the Chamber concluded that the purpose to inform and protect is a legitimate one. One may doubt about the value of this distinction since it seems to be evident that the State that wants to inform the Court about its legal interests, does so with the aim to protect them. It is difficult to imagine the purpose of the intervention limited to an informative purpose stricto sensu.

The safeguarding of the legal interest and the recognition of subjective rights should also be distinguished. ${ }^{89}$ In this regard, the applications of intervention submitted by Italy and Nicaragua received different treatment. While the Court found that the declared Italian purpose to protect its rights was not the real purpose and concluded that Italy "is requesting... to decide on the rights which it has claimed and not merely to ensure that these rights be not affected", 90 the Chamber found that

...it appears to the Chamber that the object stated first in Nicaragua's Application, namely 'generally to protect the legal rights of the Republic of Nicaragua in the Gulf of Fonseca and the adjacent maritime areas by all legal means available, is not to be interpreted as involving the seeking of a judicial pronouncement on Nicaragua's own claims. The 'legal means available' must be those afforded by the institution of intervention for the protection of a third State's legal interests. So understood, that object cannot be regarded as improper. ${ }^{91}$

The underlying problem of the recognition of rights of the intervening State is that in fact the Court would be adjudicating in a new dispute between the third State and one of the parties which, in the absence of jurisdictional link, is not a legitimate purpose of intervention. ${ }^{92}$

El Salvador contended that in fact Nicaragua was introducing a new dispute before the Court and that, in addition to the necessary jurisdictional link, it was "entirely premature for the issue to be brought before this Chamber", given the absence of prior negotiations among the parties involved..$^{93}$

89 ICJ Reports, 1984, pp. 23-37.

90 Ibidem, pp. 22-35, This decision was strongly critisized by Judges Ago, Sette-Camara, Mbaye and Oda for whom the Court had "rewritten" Italy's application. See ICJ Reports 1984, p. 53 (Mbaye), p. 84 (Sette-Camara), 107 (Oda) and pp. 123-125 (Ago).

91 ICJ Reports, 1990, p. 131.

92 Nicaragua, aware of the jurisprudence of the Court, stated that "no 'additional dispute' is involved" in its application for permission to intervene. ICJ Reports, 1990, p. 131, para 91.

93 ICJ Reports, 1990, p. 113, para 50. 
The Chamber dismissed the contention by concluding that “...it would... be inappropriate to require, as a condition of intervention, the existence of such a dispute, defined by prior negotiations", ${ }^{94}$ and examined "the only remaining question (on) whether a jurisdictional link is required". .5

\section{6) The problem of "jurisdictional link"}

In previous cases of intervention, the Court refused to deal explicitly with the question of jurisdictional link, leaving the problem "to be decided as and when [it] occur in practice and in the light of the circumstances of each particular case". ${ }^{96}$

The need of a jurisdictional link between the parties to a case and the intervening State as a requirement for intervention under Article 62 of the Statute of the Court, was included in the new Rules of the Court enacted in 1978, following the declarations made by certain Judges in the Nuclear Tests case in the sense that the permission to intervene granted to Fiji should be conditioned to the existence of a jurisdictional link between that State and France as respondent. ${ }^{97}$

It seems to be difficult to conceive Article $81.2 \mathrm{c}$ ) of the Rules of the Court as imposing a new requirement for intervention since, as Nicaragua rightly pointed out, "...the provision of Article 81 of the Rules of the Court cannot modify the clear terms of the Statute".$^{98}$

At the same time, the relevance of the existence of a jurisdictional link with respect to certain purposes of intervention can not be neglected. As Judge Mbaye pointed out, “...[I]l y a un lien entre l'exigence d'un lien jurisdictionnel et l'exigence de l'indication de l'objet de l'intervention". ${ }^{99}$

This was the strategy followed by Nicaragua who distinguished the cases of "proper" intervention, where the object is the protection of the legal interests of the intervening State, from those of "improper" inter-

94 ICJ Reports, 1990, p. 114, para 51. This statement follows Judge Oda's dissenting opinion in the Italian intervention attempt in the sense that “...there is no ground for believing the Court has ever concluded that either... a prior dispute or negotiations with either of the original litigants, is an implicit prerequisite for intervention under Article 62”. ICJ Reports, 1984, p. 97, para. 17.

95 ICJ Reports, 1990, p. 132, para 94.

96 ICJ Reports 1981, p. 14, para 23 and ICJ Reports 1984, p. 27-8, para. 45.

97 ICJ Reports 1974, pp. 531-33 and 536-38.

98 ICJ Reports 1990, p. 109, para. 39.

99 ICJ Reports 1984, p. 44. 
vention, where the recognition of subjective rights constitutes the purpose of the intended intervention.

In the first kind of cases, the requirement of a jurisdictional link would be unnecessary, while in cases of "improper" intervention, as far as a new dispute is introduced as between the parties and the intervening State, the existence of a jurisdictional link is a necessary corollary of the principle of consent which governs every international jurisdiction.

Therefore, according to the Nicaragua thesis, the requirement of Article $81.2 \mathrm{c}$ ) of the Rules of the Court would not be applicable in cases in which the object of the intervention is the safeguard or protection of rights.

The relationship between the purpose of the intervention and the requirement of a jurisdictional link was recognized by the Chamber: "...the nature of the competence thus created by Article 62 of the Statute is definable by reference to the object and purpose of intervention, as this appears from Article 62 of the Statute". ${ }^{100}$

In cases of "improper" intervention the basis of competence provided for in Article 62 are not sufficient for admitting an application because the intervening State is in fact introducing a new dispute as between itself and one or both of the original parties. In this regard, the Chamber clearly stressed that Article 62

It is not intended to enable a third State to tack on a new case, to become a new party, and so have its own claims adjudicated by the Court. A case with a new party, and new issues to be decided, would be a new case. The difference between intervention under Article 62, and the joining of a new party to a case, is not only a difference in degree; it is a difference in kind. ${ }^{101}$

Consequently, Article 62 of the Statute cannot be conceived as an exception to the principle of consensual jurisdiction. As the Chamber highlighted,

Intervention cannot have been intended to be employed as a substitute for contentious proceedings. Acceptance of the Statute by a State does not in itself create jurisdiction to entertain a particular case: the specific consent of the parties is necessary for that... the incidental jurisdiction conferred by 
Article 62 of the Statute is circumscribed by the general principle of consensual jurisdiction over particular disputes... ${ }^{102}$

When the purpose of the intervention is the protection of the legal interests of the intervening State, Article 62 suffices as a basis of competence:

The competence of the Court in this matter of intervention is not, like its competence to hear and determinate the dispute referred to it, derived from the consent of the parties to the case, but from the consent given by them, in becoming parties to the Court's Statute, to the Court's exercise of its powers conferred by the Statute... Thus the Court has the competence to permit an intervention even though it be opposed by one or both of the parties to the case... ${ }^{103}$

It follows "that the existence of a valid link of jurisdiction between the would-be intervener and the parties is not a requirement for the success of the application". ${ }^{104}$ Therefore, the Chamber concluded that "the absence of a jurisdictional link between Nicaragua and the Parties to this case is no bar to permission being given for intervention". ${ }^{105}$

\section{d) Status and procedural consequeces of intervention}

\section{d.1) The status of "party to the case"}

The problem of jurisdictional link is closely related to the status of the intervenig States and its procedural rights: is an intervener to be a 'party' or not to a case?

The intended status of a State intervening is not clear from the wording of Article 62 or the Rules of the Court. Nicaragua did not intend to become a party to the case, given that the purpose of its intervention was to protect its rights in the Gulf of Fonseca and the lack of jurisdictional link with the parties to the case.

Nevertheless, it considered that the appropriate protection of its rights could not be achieved with a non-party status. Therefore, it contended that its procedural status should be that of "intervening party" without 
entering in considerations as to the procedural consequences of that status. ${ }^{106}$

The Chamber had recognized the close relationship between the "object" of the intervention and the existence of "jurisdictional link" and found that that relationship has consequences regarding the status of the intervening State. ${ }^{107}$

In the first place, the Chamber concluded that by the mere fact of the intervention, the third State does not become a party to the case, and does not acquire rights nor is subject to the obligations which apply to the parties in the case: "If an intervener were held to become a party to a case merely as a consequence of being permitted to intervene in it, this would be a very considerable departure from (the) principle of consensual jurisdiction". 108

Therefore, an intervening State may become a party to the case when it has an "improper" object of intervention and the "specific consent of the parties". 109

Nicaragua, then, had the right to be heard by the Chamber, but it cannot argue either on the interpretation of the compromis (an instrument which is res inter alios acta) or on those aspects of the dispute between the parties from which it had been denied the permission to intervene. ${ }^{110}$

\section{d.2) The application of Article 31 of the Statute}

Regarding the possibility for the intervening State to appoint an $\mathrm{ad}$ hoc judge in application of Article 31 of the Statute, the Court had decided in 1981 that

....a State which seeks to intervene under Article 62 of the Statute has no other right that to submit a request to be permitted to intervene, and has yet to establish any status in relation to the case; that pending consideration of a decision on a request for permission to intervene, the conditions under which Article 31 of the Statute may become applicable does not exist. ${ }^{111}$ 
On the contrary, in the case existence of a valid link of jurisdiction between the intervening State and the parties, the third State would become a "party" in the case and, therefore, the possibility of application of Article 31 of the Statute remains open.

\section{d.3) Intervention and the principle res inter alios acta}

The status of "non-party" granted to Nicaragua in the case sub examine has to be analized, finally, in relation with the principle res inter alios acta provided for in Article 59 of the Statute of the Court.

In this regard, the Chamber stressed that

As a non-party Nicaragua is under the protection of Article 59 of the Statute of the Court and the right it has acquired by having its Application admitted is fundamentally the right to be heard by the Chamber. With respect to Nicaragua, the decision to be rendered by the Chamber on the merits will remain res inter alios acta. ${ }^{112}$

Therefore, a decision on the merits of a case is not res judicata for a non-party intervener under Article 62 of the Statute of the Court.

\section{FINAL REMARKS}

Our brief survey over the general features of intervention both under Articles 62 and 63 of the Statute of the Court, as well as the examination of the conditions under which Nicaraguan intervention was granted in El Salvador/Honduras case has shown that the Chamber has clarified and developed the interpretation of Articles 62 of the Statute and 81 of the Rules of the Court.

One of the remarkable aspects of the judgement, in our view, is the link made by the Chamber between the concepts of "interest of a legal nature", "object" of the intervention, the need for a jurisdictional link and the procedural status of the intervening State.

The Chamber has also succeded in highlighting the concept of "interest of a legal nature" and clarifying the procedural status of the intervening State. 
Nevertheless, certain criticism could be addressed to the logic behind the reasoning of the Chamber regarding the conditions of admissibility of an application for permission to intervene.

Article 81 of the Rules of the Court requires the applicant State to set out

a. the interest of a legal nature which considers may be affected by the decision;

b. the object of the intervention, and

c. any basis of jurisdiction which is claimed to exist as between itself and the parties to a case.

The Chamber has declared that if the purpose of the intervention is the protection of the interest of a legal nature of the intervening State, the lack of jurisdictional link does not bar an application for permission to intervene from being admitted.

If the purpose of the intervention is the recognition of rights of the intervening States, the existence of a jurisdictional link becomes conditio sine qua non and, in that case, the intervener would become a new party to the case.

Although this interpretation seems to be coherent, it is surprising that one of the conditions of admissibility of an application for permission to intervene becomes relevant only in those cases which are supposed to be out of the intended scope of Article 62.

If Article 62 it is "not intended to enable a third State to tack a new case, to become a new party, and so have its own claims adjudicated by the Court", 113 it is difficult to imagine under which grounds "improper" intervention would be granted.

In addition, an "improper" intervention would alter the incidental nature of the intervention. The Chamber itself has recognized that

"An incidental proceeding cannot be one which transforms that case into a different case with different parties". ${ }^{114}$

Furthermore, the Chamber stated that intervention cannot be intended to be employed as a substitute for contentious proceedings. ${ }^{115}$

For that reason, it seems to be difficult to follow the reasoning of the Chamber regarding "improper" interventions. It can be argued that interven- 
tion as a party seems to ensure a most efficient administration of justice, but we do not find in the Statute of the Court legal basis for its admission.

Taking the existence of a jurisdictional link as a condition of proper intervention under article 62 of the Statute would clearly exceed the regulatory powers of the Rules of the Court regarding the Statue, which can only be modified by the means provided for in its Article 69.

On the other hand, the recognition of subjective rights by the Court in cases of existence of a jurisdictional link between the parties to a dispute can be pursued by the introduction of a new claim before the Court.

In that circumstance, is for the Court to decide whether the proceedings should be joined or not, in accordance to Article 47 of its Rules.

Finally, the fact that the Chamber formed to deal with the case $s u b$ examine was composed by some of the Judges who expressed dissenting opinions in previous cases of intervention remains open the question as whether its conclusions would be ratified by the full Court. The decision of the Court on the Application for permission to intervene filed by Equatorial Guinea in the Cameroon v. Nigeria case it is certainly the opportunity for the Court to clarify its views on third party intervention.

\section{BIBLIOGRAPHY}

ICJ Reports, 1982, p. 18.

ICJ Rep. (1974), pp. 530-538; Case Concerning the Continental Shelf (Tunisia/Libyan Arab Jamahiriya): Application by Malta for Permission to Intervene, ICJ Rep. (1981), p. 3-40; Case Concerning the Continental Shelf (Libyan Arab Jamahiriya/Malta): Application by Italy for Permission to Intervene.

ICJ Rep. (1984), p.3-160; and Case Concerning the Land, Island and Maritime Frontier Dispute (El Salvador/Honduras)

Haya de la Torre case, ICJ Reports, 1951, p. 71 ss.

Asylum case (Colombia v. Peru), ICJ Reports, 1950, p. 266 (Judgement of 20 November).

ICJ Reports 1986.

ICJ Reports at 12, 1981.

ICJ Reports 1984, p. 151, paragraph 9.

ICJ Reports, 1990, Case Concerning the Land, Island and Maritime Frontier Dispute (El Salvador/Honduras), Application by Nicaragua for Permission to Intervene. 
ICJ Reports, 1992, p. 260; p. 53.

Judgment, ICJ Reports, 1954, p. 19.

ICJ Reports 1966, p. 34.

International Court of Justice, Press Communiqué 99/35.

ABI-SAAB, Georges, "De l'evolution de la Cour Internationale. Reflexions sur quelques tendances recentes", Revue Générale de Droit International Public.

FITZMAURICE, "The Law and Procedure of the International Court of Justice, 1951-4", BYIL, 1958.

GUYOMAR, Geneviève, Commentaire du Règlement de la Cour Internationale de Justice, Paris, Pedone.

HABSCHEID, Walther J.; "Les conditions de l'intervention volontaire dans un procès civil", in International Court of Justice (Pleadings, Oral Arguments, Documents), Case Concerning the Continental Shelf (Tunisia/Libyan Arab Jamahiriya, vol. III.

HAMBRO, Edvard, "Intervention under Article 63 of the Statute of of the International Court of Justice", Il Processo Internazionale. Studi in Onore di Gaetano Morelli, Milano, 1975.

Jennings, Robert, Case Concerning the Continental Shelf (Libyan Arab Jamahiriya/Malta), ICJ Reports 1984.

JIMÉNEZ DE ARÉCHAGA, E., "Intervention under Article 62 of the Statute of the International Court of Justice", Völkerrecht als Rechtsordnung Internationale Gerichtsbarkeit Menschenrechte-Festschrift für Hermann Mosler, Springer Verlag, Berlin-Heildelberg-New York, 1983.

KoHEN, Marcelo, "La requête à fin d'intervention du Nicaragua dans l'affaire du Differend Frontalier Terrestre, Insulaire et Maritime (El Salvador/Honduras). L'Ordonnance de la Cour du 28 fèvrier 1990 et l'arrêt de la Chambre du 13 septembre 1990", Annuaire Français de Droit International, XXXVI, 1990.

RIQUELME CORTADO, Rosa Ma., La intervencion de terceros Estados en el proceso internacional, Madrid, Tecnos, 1993.

SHIGERU, Shigeru, "Intervention in the International Court of Justice. Articles 62 and 63 of the Statute", Völkerrecht als Rechtsordnung Internationale Gerichtsbarkeit Menschenrechte-Festchrift für Hermann Mosler. 